\title{
GDF15 wt Allele
}

National Cancer Institute

\section{Source}

National Cancer Institute. GDF15 wt Allele. NCI Thesaurus. Code C52014.

Human GDF15 wild-type allele is located within 19p13.1-13.2 and is approximately $3 \mathrm{~kb}$ in length. This allele, which encodes growth/differentiation factor 15 protein, plays a role in the regulation of tissue differentiation and maintenance. 